\title{
PENINGKATAN STATUS BESI DAN KEBUGARAN FISIK PEKERJ A WANITA USIA SUBUR
}

\author{
(Improving the Iron Status and Physical Fitness of the Reproductive Female Workers)
}

\author{
Yaktiworo Indriani ${ }^{2}$, Ali Khomsan ${ }^{2}$, Dadang Sukandar ${ }^{2}$, Hadi Riyadi ${ }^{2}$, Reni Zuraida ${ }^{3}$
}

${ }^{1}$ Alamat Korespondensi: J urusan Sosial Ekonomi Pertanian/ Agribisnis, Fakultas Pertanian, Universitas Lampung. JI Sumantri Broj onegoro No 1, Bandar Lampung 35144

2 Departemen Gizi Masyarakat, Fakultas Ekologi Manusia, IPB, Bogor 16680

3 Fakultas Kedokteran, Universitas Lampung, Jl Sumantri Brojonegoro No 1, Bandar Lampung 35144

* Alamat Korespondensi: J urusan Sosial Ekonomi Pertanian/ Agribisnis, Fakultas Pertanian, Universitas Lampung. J I Sumantri Broj onegoro No 1, Bandar Lampung 35144. Telp/ faks: 0721-781821; email: yakti_indriani@yahoo.com

\begin{abstract}
ABST RACT
The study aims were to (1) assess the nutritional status, adequacy level, and physical fitness of the nonpregnant reproductive female workers, and (2) analyze the effect of micronutrients supplementation on their iron status and physical fitness. This research employed experimental design of double blind, completely randomized design by involving 338 households of female workers. The experimental unit consists of 39 female workers whose hemoglobin level were 80-125 g/ L. However, five of them were drop out due to pregnancy or sickness. The treatments applied in the study were three capsules containing: (1) iron and folic acid (BF), (2) multi-vitamin and mineral (MVM), which contains of 15 different vitamins and minerals, and (3) placebo (P). The body mass index of the female workers were thin 12 percent, normal 70 percent and overweight 18 percent. Most of their nutritional intake of vitamin C, calcium and iron were deficient but they had a good to superior of physical fitness. After 10 weeks of three days per week supplementation, BF significantly increased the hemoglobin $(p<0.05)$ as $8.6 \mathrm{~g} / \mathrm{L}$ and ferritin as $10.1 \mu \mathrm{g} / \mathrm{L}$; while MVM only increased the hemoglobin as $6.8 \mathrm{~g} / \mathrm{L}$. The micronutrient supplements of BF and MVM groups could improve the physical fitness $\left(\mathrm{VO}_{2} \max \right)$ of the anemia famale workers by 13 percent and 14 percent.
\end{abstract}

Key words: female workers, iron status, physical fitness, iron folic acid, multi-vitamin and mineral

\section{PENDAHULUAN}

Sebagian besar pekerja wanita di Indonesia termasuk dalam golongan wanita usia subur (WUS) yang beresiko tinggi mengalami anemia sehingga memerlukan perhatian dan penanganan secara khusus. Anemia adalah keadaan kadar hemoglobin $(\mathrm{Hb})$ di darah lebih rendah dibandingkan nilai normal untuk jenis kelamin dan usianya. Untuk WUS, dinyatakan anemia jika $\mathrm{Hb}<120 \mathrm{~g} / \mathrm{L}$ Prevalensi anemia gizi besi (AGB) di Indonesia pada WUS tahun 2007 masih berada pada kategori sedang, yakni 19.7 persen dan secara khusus pada ibu hamil mencapai 24.5 persen (BPPK Depkes RI 2008). Prevalensi anemia pada WUS hamil yang lebih tinggi diperkirakan karena wanita tersebut telah mengalami anemia jauh sebelum hamil. Untuk menurunkan prevalensi anemia pada wanita hamil, seyogyanya mereka sudah diberi suplemen zat besi (Fe) sebelum hamil. Dengan demikian mereka dapat memasuki masa kehamilannya dalam kondisi tidak anemia.
Banyak penelitian yang telah membuktikan bahwa pemberian zat besi (Fe) dapat meningkatkan kadar $\mathrm{Hb}$ dan produktivitas pekerja wanita yang anemia (WB 2006). Li (1994) di China membuktikan bahwa pemberian $\mathrm{Fe}$ pada pekerja wanita anemia dapat meningkatkan $\mathrm{Hb}$ dan serum feritin (SF) serta menurunkan denyut jantung saat bekerja. Pemberian Fe dikombinasi dengan asam folat atau vitamin dan mineral lainnya kepada remaja putri di Bangladesh yang anemia, selain meningkatkan $\mathrm{Hb}$ dan $\mathrm{SF}$, juga dapat menurunkan prevalensi kekurangan beberapa vitamin (Ahmed et al. 2005). Penelitian lainnya di Indonesia membuktikan bahwa pemberian $\mathrm{Fe}$ yang dikombinasikan dengan berbagai vitamin dan mineral dapat memperbaiki status gizi besi ( $\mathrm{Hb}$, hematokrit-Ht dan SF) serta menurunkan prevalensi anemia pada pekerja wanita dan remaja putri lanjut (Ekayanti 2005; Briawan 2008). Suplemen besi folat (BF) yang mengandung $60 \mathrm{mg} F e$ ditambah $400 \mu \mathrm{g}$ asam folat disarankan oleh INACG (2003) untuk WUS 
sebagai usaha preventif untuk mencegah mengalami kesulitan melahirkan pada saat dia nanti hamil. Adapun UNICEF/ WHO/ UNU (1999) menyarankan guna memperbaiki status gizi WUS diperlukan multi vitamin mineral (MVM) yang berisi 15 macam vitamin dan mineral karena mereka tidak cukup hanya diberi suplemen Fe dan asam folat saja. Pemberian kapsul MVM diharapkan dapat memelihara homeostasis besi dalam darah.

Saat ini banyak WUS baik yang sudah maupun belum menikah bekerja di sektor industri. Pekerja WUS tersebut sehari-harinya bekerja dalam ruang yang cukup panas dan berisik. Oleh karena itu mereka perlu kesehatan dan kebugaran fisik yang prima. Pertanyaan yang muncul adalah bagaimanakah status dan kecukupan gizi serta kebugaran fisik pekerja WUS yang memiliki kadar hemoglobin marginal. Masalah menarik untuk diteliti lebih lanjut adalah bagaimanakah pengaruh pemberian suplemen zat gizi mikro terhadap status besi dan kebugaran fisik pekerja wanita tersebut.

Tujuan Penelitian ini adalah untuk: (1) menganalisis status dan tingkat kecukupan gizi serta kebugaran fisik pekerja wanita yang memiliki kadar $\mathrm{Hb}$ marginal dan (2) mengkaji pengaruh pemberian zat gizi mikro terhadap status besi (Hemoglobin, serum feritin dan serum tranferin reseptor) serta kebugaran fisik (laju denyut jantung dan $\mathrm{VO}_{2}$ maks) mereka.

\section{METODE}

\section{Desain dan Lokasi}

Penelitian ini merupakan kelanjutan dari penelitian yang berjudul "Study on the Nutritional Status and Physical Fitness of the Non Pregnant Woman Workers to Support the Household Socio-Economy" (Indriani, Riyadi, \& Zuraida 2011), yang menggunakan metode survei dengan melibatkan 338 sampel rumah tangga pekerja wanita. Adapun penelitian ini menggunakan rancangan percobaan (experimental design) rancangan acak lengkap-RAL (completely randomized design-CRD). Perlakuan yang diberikan adalah suplementasi atau pemberian tambahan zat gizi mikro dalam kemasan kapsul secara buta ganda (double blind).

Penelitian ini dilakukan di perusahaan pengalengan nanas yang terletak di Kabupaten Lampung Tengah, Provinsi Lampung. Perusahaan tersebut memiliki perkebunannya sendiri, sehingga terjamin bahan bakunya dan dapat berproduksi secara kontinyu. Penelitian pendahuluan dilakukan pada bulan JuniAgustus 2010, sedangkan penelitian eksperimen dilaksanakan bulan Oktober 2010 hingga J anuari 2011.

\section{Cara Pemilihan Sampel}

Unit percobaan atau subyek penelitian ini adalah pekerja wanita usia subur yang memiliki kadar $\mathrm{Hb}$ marginal berdasarkan penelitian pendahuluan (Indriani et al. 2011), untuk selanjutnya disebut pekerja wanita. Kriteria "Hb marginal" adalah mengalami "anemia" dengan kadar $\mathrm{Hb}$ 80-119 g/ L, dan Hb termasuk normal namun di ambang batas bawah dengan kadar Hb 120-125 g/ L, ini merupakan kelompok yang perlu mendapatkan tindakan gizi melalui pendidikan dan pencegahan (Carley 2003). Kriteria inklusi unit percobaan adalah pekerja wanita berusia 18-45 tahun, memiliki kadar $\mathrm{Hb}$ 80-125 g/ L, sudah menikah, tidak sedang hamil, mengisi informed concern, tidak minum alhohol serta tidak merokok. Kriteria eksklusi adalah menderita sakit berat (jantung, hipertensi) sedang dalam masa pengobatan penyakit kronis seperti TBC; tidak bisa minum kapsul.

Jumlah subyek penelitian ditentukan menggunakan rumus dengan pertimbangan $\alpha=$ 0.05 dan $\beta=0.20$ (power of test $=80 \%$ ) serta mengacu hasil penelitian Li et al. (1994) tentang suplementasi zat besi pada pekerja wanita usia subur yang anemia di mana untuk $\mathrm{Hb}$ memiliki $\sigma=12 \mathrm{~g} / \mathrm{L}$ dan $\delta=13 \mathrm{~g} / \mathrm{L}$, sedangkan untuk SF memiliki $\sigma=18.9 \mu \mathrm{g} / \mathrm{L}$ dan $\delta=20.3$ $\mu \mathrm{g} / \mathrm{L}$. Berdasarkan pertimbangan tersebut didapatkan jumlah subyek minimal per perlakuan adalah 11 orang. Dengan mempertimbangkan kemungkinan ada subyek yang keluar, maka jumlah sampel per perlakuan ditambah 2 orang $(20 \%)$ sehingga total unit percobaan adalah 39 orang. Pengacakan dilakukan untuk menempatkan setiap unit percobaan pada perlakuannya. Protokol (Nomor Protokol 021005068) penelitian ini telah men-dapatkan persetujuan Etik (Ethical Approval) dari Komisi Etik Badan Penelitian dan Pengembangan Kesehatan Kementerian Kesehatan Nomor LB. 03. 04/ KE/ 5581/ 2010.

\section{Faktor, Perlakuan dan Peubah Respon}

Dalam penelitian ini hanya ada satu faktor yang diteliti sehingga otomatis menjadi perlakuan. Terdapat tiga grup perlakuan yang merupakan jenis suplemen yaitu BF (berisi Ferrous sulfat $200 \mathrm{mg}$ yang setara dengan zat besi elemental $60 \mathrm{mg}$ dan asam folat $400 \mu \mathrm{g}$ ) 
yang diperoleh dari apotik, MVM (multi vitamin dan mineral yang terdiri dari 15 macam vitamin dan mineral yaitu vitamin A $800 \mu \mathrm{g}$, D $200 \mathrm{IU}, \mathrm{E} 10 \mathrm{mg}$, vit C $70 \mathrm{mg}$, vit $B_{1} 1.4 \mathrm{mg}$, vit $B_{2} 1.4 \mathrm{mg}$, vit $B_{3} 18 \mathrm{mg}$, vit $B_{6} 1.9 \mathrm{mg}$, vit $B_{12}$ $1.9 \mu \mathrm{g}$, asam folat $400 \mu \mathrm{g}$, besi elemental 30 $\mathrm{mg}$, seng $15 \mathrm{mg}$, tembaga $2 \mathrm{mg}$, selenium 65 $\mu \mathrm{g}$, yodium $150 \mu \mathrm{g}$ ) yang diperoleh dari kantor WHO di Jakarta, Indonesia, dan P (placebo) yang berisi amilum berfungsi sebagai kontrol. Suplemen dikemas dalam kapsul yang sama warna dan ukuran setiap minggu oleh seorang apoteker kemudian dimasukan dalam tabung obat dan diberi label nama pekerja wanita. Kapsul suplemen diberikan tiga kali per minggu selama 2.5 bulan (10 minggu).

Terdapat tiga peubah respon untuk status besi dalam darah yaitu $\mathrm{Hb}$, serum ferritin (SF), dan serum transferin reseptor (STfR). Adapun kebugaran fisik diukur dengan cara menghitung $\mathrm{VO}_{2}$ maks yang merupakan suatu ukuran seberapa bugar (fit) seseorang, yang dinyatakan dengan volume oksigen yang dikonsumsi tubuh per menit sehingga satuannya adalah mL/ kg/menit (Marley 1982; Sharkey 1991; Quinn 2008). Nilai $\mathrm{VO}_{2}$ maks pekerja wanita dinilai berdasarkan pengukuran laju denyut jantung dengan cara melakukan uj i bangku A-R (Astrand-Ryhming Step Test) dengan mengadopsi protokol Astrand-Ryhming Step Test Norms For College Students (Marley \& Linnerud 1976). Setiap peubah respon diukur dua kali, yaitu sebelum dan sesudah suplementasi dan sebelum uji bangku dilakukan pengukuran tekanan darah untuk memastikan bahwa pekerja tidak memiliki tekanan darah tinggi. Untuk mengendalikan kualitas data, wawancara dilakukan langsung oleh peneliti dibantu asisten peneliti bergelar sarjana gizi yang sudah berpengalaman dalam beberapa penelitian sebelumnya dan diberi pelatihan sebelum melakukan penelitian ini. Pengambilan contoh darah sebanyak $3 \mathrm{~mL}$ dari vena cubiti dan penilaian laju denyut jantung dilakukan oleh paramedis di bawah supervisi seorang dokter.

Seminggu sebelum dimulai suplementasi, dilakukan pemberian obat cacing untuk menghilangkan pengaruh infestasi cacing, dan uj i laju endap darah (LED) untuk mengetahui kemungkinan adanya infeksi (radang). Selain itu, dilakukan penilaian status gizi antropometri yakni indeks massa tubuh (IMT) yang merupakan perbandingan antara berat badan $(\mathrm{kg})$ dengan tinggi badan kuadrat $\left(\mathrm{m}^{2}\right)$, persentase lemak tubuh ( $\%$ B $)$ serta pengeluaran energi (kkal) dan asupan zat gizi melalui recall makanan selama 24 jam sebelumnya selama dua hari. Analisis kadar $\mathrm{Hb}$ menggunakan mesin analisis hematologi dan LED di sebuah Laboratorium swasta bekerja sama dengan Fakultas Kedokteran Universitas Lampung di Bandar Lampung. Kadar SF dan STfR diuji dengan metode Enzym-linked immunoassays (ELISA) menggunakan alat Labsystem di Laboratorium SEAMEO Tropmed RCCN Universitas Indonesia di J akarta.

\section{Pengolahan dan Analisis Data}

Data karakteristik sosial ekonomi meliputi Pengolahan data mencakup pengeditan kuesioner, pengkodean, penyusunan file, pemasukan data, pengeditan file, penyusunan variabel, pengombinasian dan pemisahan file.

Data jumlah pangan yang dikonsumsi dikonversikan ke dalam energi dan zat gizi meliputi, protein, vitamin $A$, vitamin $C$, zat besi, kalsium, dan fosfor dengan menggunakan DKBM (Depkes RI 1970, 1995, 2001, 2005). Pengukuran tingkat kecukupan gizi (\%AKG) dilakukan dengan membandingkan kandungan zat gizi semua makanan yang dimakan oleh pekerja WUS selama 24 jam dengan AKG 2004 (WNPGI 2004) dalam persen. Selain energi, zat gizi lain yang dihitung tingkat kecukupan-nya adalah protein, vitamin A, vitamin C, fosfor, kalsium, dan zat besi. Untuk menganalisis perubahan data sebelum dan sesudah suplementasi dilakukan uji beda rerata (uji t). Pengukuran pengeluaran energi dilakukan dengan menghitung energi per aktivitas selama 24 jam. Untuk membandingkan data antar perlakuan dan pengaruh suplementasi antar perlakuan diuji dengan ANOVA dan uji lanjut Duncan.

\section{HASIL DAN PEMBAHASAN}

\section{Karakteristik Pekerja Wanita}

Pekerja wanita anemia marginal yang berhasil mengikuti suplementasi sampai selesai berjumlah 34 orang. Terdapat 5 orang (13\%) pekerja wanita yang gugur dikarenakan 3 orang hamil, dan 2 orang sakit. Berdasarkan uj $\mathrm{t}$, tidak ada perbedaan data awal yang nyata ( $p=0.37-0.96)$ dalam rerata berat badan (BB), tinggi badan (TB), indeks IMT, Hb, SF, STfR dan $\mathrm{VO}_{2}$ maks antara 39 orang dengan 34 orang yang memiliki data lengkap. Rerata

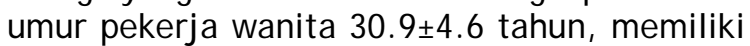
$1.0 \pm 0.8$ anak, dan lama kerja di perusahaan

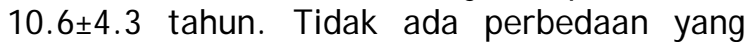
nyata antar perlakuan pada ketiga karakteristik pribadi tersebut. 
Hasil analisis untuk laju endap endap darah (LED) 1 jam dan 2 jam sebelum suplementasi menunjukkan angka yang cukup tinggi yakni $26.2 \pm 16.0 \mathrm{ml} / \mathrm{jam}$ dan $49.6 \pm 24.9$ $\mathrm{ml} / \mathrm{jam}$, ini merupakan indikasi adanya gangguan kesehatan dalam tubuh pekerja wanita. Pada penderita anemia LED cenderung tinggi seiring dengan rendahnya $\mathrm{Hb}$. Pemeriksaan LED secara berulang dapat digunakan untuk memonitor keberhasilan terapi/pengobatan. Sesudah suplementasi, LED pekerja wanita pada semua perlakuan turun $(p \measuredangle 0.05)$ menjadi $12.4 \pm 7.3$ dan $25.1 \pm 12.5 \mathrm{~mL} /$ jam. Ini mendekati standar normal (10-20 $\mathrm{mL} / \mathrm{jam})$ dan menunjukkan terjadi perbaikan kesehatan melalui pemberian zat gizi mikro. Perbedaan penurunan LED antar perlakuan tidak berbeda nyata yakni pada BF - 14.8 dan -24.4 mL/ jam, pada MVM 14.5 dan $-23.7 \mathrm{~mL} /$ jam, serta pada $\mathrm{P}-12.1$ dan $-25.2 \mathrm{~mL} / \mathrm{jam}$.

\section{Suplementasi Kapsul}

Pelaksanaan suplementasi dilakukan di depan peneliti atau asisten peneliti setiap hari Selasa, Rabu dan Jum'at di balai pengobatan yang terletak di dekat pabrik. Waktu minum kapsul adalah sesudah makan siang, bagi yang kerja pagi, atau sesudah makan malam bagi yang kerja malam. Kepatuhan minum kapsul semua 100 persen. Manfaat kapsul yang dirasakan pekerja wanita cukup bervariasi. Manfaat yang dilaporkan oleh ketiga perlakuan adalah merasa badan lebih enak dan bertenaga $(62 \%)$ diikuti oleh nafsu makan bertambah (47\%) dan tidur lebih nyenyak (24\%). Ini menunjukkan bahwa pemberian sugesti di awal saja dapat berpengaruh positif terhadap grup plasebo (placebo effect), bahkan pekerja wanita yang paling banyak melaporkan tidur lebih nyenyak berasal dari grup $P$.

\section{Status Gizi Antropometri, Kecukupan Gizi, dan Pengeluaran Energi}

Status gizi, adalah keadaan tubuh yang diakibatkan oleh konsumsi, penyerapan dan penggunaan makanan. Indek masa tubuh (IMT) merupakan ukuran antropometri yang baik digunakan pada orang dewasa yang memberikan gambaran mengenai asupan gizi seseorang di masa lalu dan dibandingkan dengan masa kini. Pada Tabel 1 dapat dilihat status gizi antropometri pekerja wanita sebelum dan sesudah suplementasi.

Secara umum tidak ada perbedaan yang nyata antar perlakuan pada beberapa peubah status gizi sebelum suplementasi ( $p>0.05)$. Sebelum suplementasi, 12 persen pekerja wanita termasuk kurus (IMT< $\left.<18.5 \mathrm{~kg} / \mathrm{m}^{2}\right), 70$ persen normal, dan 18 persen gemuk (IMT>25 $\mathrm{kg} / \mathrm{m}^{2}$ ). Sesudah suplementasi, angka-angka tersebut menjadi 6 persen, 73 persen, dan 21 persen. Sesudah suplementasi, berat badan dan IMT pada ketiga perlakuan meningkat secara nyata $(p<0.005)$, namun peningkatannya antar perlakuan tidak berbeda nyata $(p>0.05)$. Terjadinya peningkatan ini sesuai dengan pernyataan pekerja wanita di atas bahwa selama suplementasi nafsu makan bertambah, sehingga IMTnya naik. Peningkatan yang terjadi pada ketiga peubah tersebut dapat menjelaskan bahwa suplementasi yang dilakukan kepada pekerja wanita dapat diterima.

Asupan zat gizi pekerja wanita sebelum dan selama suplementasi tidak berbeda nyata baik di dalam maupun antar perlakuan. Pada Tabel 2 dapat dilihat bahwa asupan zat gizi (kecuali vitamin C) selama suplementasi lebih tinggi dibandingkan dengan sebelumnya. Hal ini sesuai dengan respon di atas yang menyatakan nafsu makannya bertambah sehingga berat badan dan IMT setelah suplementasi naik.

Tabel 1. Karakteristik Antropometri Pekerja Wanita menurut Perlakuan

\begin{tabular}{|c|c|c|c|c|c|}
\hline \multicolumn{2}{|c|}{ Karakteristik antropometri } & BF $(n=11)$ & MVM (n=11) & $P(n=12)$ & p-value \\
\hline \multirow{3}{*}{$\begin{array}{l}\text { Berat badan } \\
(\mathrm{kg})\end{array}$} & Sebelum & $47.4 \pm 6.7$ & $50.1 \pm 7.5$ & $48.0 \pm 7.2$ & 0.410 \\
\hline & Sesudah & $48.5 \pm 6.7^{2}$ & $51.7 \pm 6.9^{3}$ & $48.8 \pm 6.6^{3}$ & 0.487 \\
\hline & $\Delta \mathrm{BB}$ & $1.1 \pm 1.3$ & $0.7 \pm 0.8$ & $0.9 \pm 1.1$ & 0.620 \\
\hline \multirow{3}{*}{$\begin{array}{l}\text { Tinggi badan } \\
(\mathrm{cm})\end{array}$} & Sebelum & $151.8 \pm 4.5$ & $152.2 \pm 7.4$ & $149.0 \pm 4.8$ & 0.475 \\
\hline & Sesudah & $152.0 \pm 4.6$ & $151.0 \pm 7.4$ & $149.0 \pm 4.3$ & 0.426 \\
\hline & $\Delta \mathrm{TB}$ & $0.2 \pm 0.2^{\mathrm{a}}$ & $0.2 \pm 0.2^{\mathrm{a}}$ & $0.0 \pm 0.2^{\mathrm{b}}$ & 0.032 \\
\hline \multirow{3}{*}{$\begin{array}{l}\text { Indeks Massa } \\
\text { Tubuh }\left(\mathrm{kg} / \mathrm{m}^{2}\right)\end{array}$} & Sebelum & $20.6 \pm 2.8$ & $22.5 \pm 3.4$ & $21.6 \pm 3.2$ & 0.361 \\
\hline & Sesudah & $21.0 \pm 2.8^{2}$ & $22.9 \pm 3.5^{3}$ & $22.1 \pm 3.3^{3}$ & 0.400 \\
\hline & $\Delta \mathrm{IMT}$ & $0.5 \pm 0.6$ & $0.4 \pm 0.5$ & $0.4 \pm 0.5$ & 0.952 \\
\hline
\end{tabular}

1 p-value, hasil analisis ragam (uji anova) pada baris yang sama

2,3 Berbeda nyata dari sebelum suplementasi (uj i-t: ${ }^{2} p \varangle 0.01,{ }^{3} p \varangle 0.05$ )

$a, b$ Huruf yang sama dalam satu baris menunjukkan tidak ada perbedaan yang nyata antar perlakuan (uj i anova, $p>0.05$ )

$\Delta=$ selisih antara sesudah dengan sebelum 
Tabel 2. Rerata Asupan Zat Gizi dan Tingkat Kecukupan Gizi (\%AKG)

\begin{tabular}{cccccccc}
\hline \multicolumn{1}{c}{ Konsumsi } & Energi (kkal) & Protein (g) & Vit. A (RE) & Vit. C (mg) & Ca (mg) & P (mg) & Fe (mg) \\
\hline Sebelum Suplementasi & 1582 & 43.0 & 846 & 51 & 303 & 747 & 13.4 \\
Selama Suplementasi & 1776 & 47.8 & 1608 & 45 & 864 & 1046 & 14.4 \\
\hline \multicolumn{1}{c}{ \% AKG } & Energi (\%) & Protein (\%) & Vit. A (\%) & Vit. C (\%) & Ca (\%) & P (\%) & Fe (\%) \\
\hline Sebelum Suplementasi & 97.8 & 87.7 & 251.7 & 106.9 & 48.4 & 165.9 & 58.6 \\
Selama Suplementasi & 106.7 & 95.7 & 356.0 & 65.4 & 120.8 & 318.1 & 60.1 \\
\hline
\end{tabular}

Secara individu, asupan zat gizi mikro untuk vitamin $C$ (meskipun secara total reratanya normal), Ca dan zat besi sebagian besar baik sebelum dan selama suplementasi berada dalam kategori defisit (\%AKG $<70 \%$ ). Sebelum dilakukan suplementasi jumlah pekerja wanita yang mengalami defisit untuk vitamin $\mathrm{C}, \mathrm{Ca}$ dan Fe sebanyak 74 persen, 82 persen, dan 62 persen; sedangkan selama suplementasi sebanyak 74 persen, 71 persen dan 65 persen. Kemungkinan ini salah satu penyebab mereka mengalami anemia. Vitamin $\mathrm{C}$ berperan membantu penyerapan zat besi non-heme dengan merubah bentuk ferri menjadi bentuk ferro dan merupakan salah satu senyawa yang paling dikenal sebagai enhancher, yang mempengaruhi ketersediaan mineral besi usus.

Rerata pengeluaran energi pekerja wanita selama suplementasi, yang dinilai secara recall berdasarkan jenis dan lama aktivitas per hari, tidak berbeda nyata antar perlakuan. Pengeluaran energi pada BF, MVM, dan P berturut-turut adalah $2150 \pm 174 \mathrm{kkal}, 2283 \pm 217$ kkal, dan 2159+202 kkal. Pengeluaran tersebut lebih tinggi dibandingkan dengan konsumsinya. Ini menunjukkan bahwa meskipun konsumsi selama suplementasi lebih tinggi dibandingkan sebelumnya, tetapi tetap belum bisa memenuhi kebutuhan rielnya.

\section{Status Besi}

Zat besi dalam saluran cerna tubuh diangkut oleh transferin mukosa dan dalam aliran darah diangkut oleh transferin reseptor.
Banyaknya serum transferin reseptor (STfR) mencerminkan keseimbangan antara kebutuhan besi seluler dan pasokan besi. Bentuk simpanan besi dalam tubuh adalah feritin atau hemosiderin dalam hati, limpa dan sumsum tulang. Feritin yang bersirkulasi dalam darah mencerminkan simpanan besi di dalam tubuh. Pengukuran feritin di serum (SF) merupakan indikator penting untuk menilai status besi (IOM-FNB 2001). Sebagian simpanan besi dimobilisasi untuk keperluan tubuh seperti pembentukan hemoglobin. Hemoglobin merupakan bagian sel darah merah yang berfungsi mengangkut oksigen melalui aliran darah dari paruparu ke jaringan tubuh yang lain dan merupakan indikator utama untuk menunjukkan tingkat kekurangan besi. Adapun hematokrit adalah perbandingan sel darah merah terhadap volume darah total (Gibson 2005).

Rerata kadar $\mathrm{Hb}$ pekerja wanita sebelum suplementasi $110 \pm 9.8 \mathrm{~g} / \mathrm{L}$, cenderung lebih rendah $(p=0.12)$ dibandingkan kadar $\mathrm{Hb}$ saat studi pendahuluan $112 \pm 10.6 \mathrm{~g} / \mathrm{L}$. Ini mengindikasikan bahwa mereka perlu diberi suplemen $\mathrm{Fe}$. Kategori status anemia mereka adalah anemia sedang 18 persen, ringan 64 persen, dan sisanya di ambang batas normal 18 persen. Sesudah suplementasi menjadi anemia sedang 3 persen, anemia ringan 18 persen, ambang batas normal 26 persen, dan normal $(\mathrm{Hb}>125$ $\mathrm{g} / \mathrm{L}) 53$ persen. Kadar $\mathrm{Hb}$ sebelum dan sesudah suplementasi antar ketiga perlakuan tidak berbeda nyata. Namun kadar SF dan STfR sesudah suplementasi berbeda nyata (Tabel 3).

Tabel 3. Kadar Hb, SF, dan STfR menurut J enis Perlakuan

\begin{tabular}{|c|c|c|c|c|c|}
\hline \multicolumn{2}{|c|}{ Status Besi } & $B F(n=11)$ & MVM $(n=11)$ & $P(n=12)$ & $p^{1}$ \\
\hline \multirow{3}{*}{$\mathrm{Hb}(\mathrm{g} / \mathrm{I}):$} & Sebelum & $107.5+11.3$ & $112.0 \pm 7.4$ & $111.7 \pm 10.5$ & 0.499 \\
\hline & Sesudah & $125.7 \pm 4.5^{2}$ & $128.6 \pm 8.7^{2}$ & $121.3 \pm 10.1^{2}$ & 0.114 \\
\hline & $\Delta \mathrm{Hb}$ & $18.2+11.6^{\mathrm{a}}$ & $16.4 \pm 7.3^{\mathrm{a}}$ & $9.6 \pm 4.0^{\mathrm{b}}$ & 0.039 \\
\hline \multirow{3}{*}{ SF(ug/I): } & Sebelum & $23.9 \pm 20.2$ & $28.7 \pm 26.6$ & $17.0 \pm 17.4$ & 0.437 \\
\hline & Sesudah & $34.03 \pm 22.1^{3 a}$ & $31.2 \pm 15.7^{\mathrm{a}}$ & $16.6 \pm 13.9^{b}$ & 0.049 \\
\hline & $\Delta \mathrm{SF}$ & $10.1+16.8$ & $2.4 \pm 23.4$ & $-0.5 \pm 23.9$ & 0.494 \\
\hline \multirow{3}{*}{$\operatorname{STfR}(\mathrm{mg} / \mathrm{l})$ : } & Sebelum & $6.0 \pm 1.7$ & $5.8 \pm 2.3$ & $6.3 \pm 3.3$ & 0.902 \\
\hline & Sesudah & $7.4+2.2^{a}$ & $5.7 \pm 1.5^{b}$ & $8.0 \pm 2.2^{a}$ & 0.028 \\
\hline & $\Delta \mathrm{STfR}$ & $1.4 \pm 3.1$ & $-0.2+1.9$ & $1.0 \pm 2.7$ & 0.237 \\
\hline
\end{tabular}

1 p-value, hasil analisis ragam (uji anova) pada baris yang sama

2,3 Berbeda nyata dari sebelum suplementasi (uji-t: ${ }^{2} p \varangle 0.01,{ }^{3} p \varangle 0.05$ )

a,b Huruf yang sama dalam satu baris menunjukkan tidak ada perbedaan yang nyata antar perlakuan (uji anova, $p>0.05$ )

$\Delta=$ selisih antara sesudah dengan sebelum 
Sesudah suplementasi semua pekerja wanita mengalami peningkatan $\mathrm{Hb}$ secara nyata dan selisih $\mathrm{Hb}$ antar perlakuan berbeda nyata $(p<0.05)$. Meskipun $\mathrm{Hb}$ meningkat, pada grup MVM dan $\mathrm{P}$ masih ada yang tetap anemia masing-masing sebanyak 27 persen dan 33 persen, sedangkan pada BF tidak ada lagi yang anemia. Secara total, pekerja wanita yang anemia tinggal 21 persen. Persentase peningkatan $\mathrm{Hb}$ tertinggi pada BF yaitu 17 persen, diikuti MVM 15 persen serta P 9 persen. Meskipun peningkatan $\mathrm{Hb}$ pada MVM lebih rendah dibandingkan BF namun perbedaannya tidak nyata sehingga dapat dikatakan bahwa BF dan MVM sama baiknya dalam meningkatkan $\mathrm{Hb}$. Peningkatan $\mathrm{Hb}$ pada BF dan MVM di atas lebih tinggi dibandingkan dengan penelitian dengan subyek remaja putri yang dilakukan oleh Ahmed et al. (2005) sebesar $6.2 \pm 0.8 \mathrm{~g} / \mathrm{L}$ dan $6.3 \pm 0.8 \mathrm{~g} / \mathrm{L}$. Demikian pula jika dibandingkan Briawan (2008), dengan memberikan BF dan BMV (besi-multivitamin) dapat meningkatkan $\mathrm{Hb}$ remaja wanita (late adolescent) sebesar $11.2 \pm 12.6 \mathrm{~g} / \mathrm{L}$ dan $10.5 \pm 12.0 \mathrm{~g} / \mathrm{L}$.

Peningkatan kadar $\mathrm{Hb}$ yang terjadi pada plasebo mungkin karena selama suplementasi terjadi peningkatan asupan energi 358 kkal, protein $11.8 \mathrm{~g}$, dan zat besi $1.9 \mathrm{mg}$. Peningkatan tersebut lebih tinggi dibandingkan pada BF berturut-turut sebesar $-23.4 \mathrm{kkal},-0.6 \mathrm{~g}$ dan $0.4 \mathrm{mg}$; serta pada MVM sebesar $214 \mathrm{kkal}, 2.7$ g, $0.5 \mathrm{mg}$. Selain itu, dengan minum kapsul muncul sugesti yang membuat tubuh secara alami mampu meningkatkan kadar $\mathrm{Hb}$ (placebo effect). Meskipun meningkat, secara statistik peningkatan $\mathrm{Hb}$ pada $\mathrm{P}$ tersebut lebih kecil dibandingkan dengan peningkatan pada BF $(p \measuredangle 0.05)$ dan MVM $(p \measuredangle 0.10)$. Selisih bersih $H b$ pada BF dan MVM jika dikoreksi dengan $P$ adalah $8.6 \mathrm{~g} / \mathrm{L}(8 \%)$ dan $6.8 \mathrm{~g} / \mathrm{L}(6 \%)$. Ini lebih tinggi dibandingkan dengan selisih bersih BF dan B-MV berkisar 2-3 g/ L dalam Briawan (2008).

Perubahan kadar SF terbesar sesudah sup lementasi juga terjadi pada BF yakni naik sebesar 42 persen $(p<0.05)$. Pada MVM, kenaikan SF hanya sebesar 8.4 persen, berarti dosis MVM baru bisa digunakan untuk menaikkan $\mathrm{Hb}$ namun belum bisa menaikkan SF. Secara statistik perubahan SF antar perla-kuan tidak nyata. Penurunan SF pada grup $P(-2.8 \%$, terjadi pada 60 persen pekerja wanita. Berbeda dengan SF, perubahan STfR terbaik terjadi pada MVM dimana sesudah suple-mentasi kadar STfR pada MVM turun dan berbeda nyata $(p=0.005)$ dengan BF dan $P$. Ini menunjukkan adanya perbaikan transportasi besi dalam jaringan tubuh MVM dan sebaliknya tidak terjadi pada BF dan Plasebo.

\section{Kebugaran Fisik}

Kebugaran fisik adalah kemampuan tubuh seseorang untuk melakukan tugas pekerjaannya sehari-hari tanpa menimbulkan kelelahan yang berarti dan masih mempunyai cadangan tenaga untuk menikmati waktu senggang serta untuk keperluan mendadak. Untuk mendeteksi kebugaran fisik pekerja wanita secara cepat dilakukan dengan pengukuran lemak tubuh. Menurut Marley (1982) dan Quinn (2008), lemak tubuh yang berlebihan akan mengurangi komponen kebugaran lain, mengurangi kinerja, menganggu penampilan, dan akan berpengaruh negatif terhadap kesehatan secara umum. Berdasarkan pengukuran, \%B pekerja wanita sebelum suplementasi dan setelah suplementasi tidak berbeda nyata antar perlakuan. Namun demikian pada masingmasing perlakuan meningkat nyata. Selang \% LB awal sebesar 14.3-40.1 persen naik menjadi 16.8-41.8 persen. Selisih \%B antar perlakuan tidak berbeda $(p>0.05)$. Pekerja wanita yang memiliki \%B di bawah 20 persen (kurus), di awal sebanyak 35 persen turun menjadi 20 persen setelah suplementasi. Namun, yang me miliki \%B berlebih tidak berubah, yakni tetap 26 persen (Tabel 4).

Kebugaran fisik berdasarkan daya tahan jantung-paru (cardiorespiratory endurance) da lam penelitian ini dinilai dengan mengukur $\mathrm{VO}_{2}$ maksimal $\left(\mathrm{VO}_{2}\right.$ maks $)$ melalui uji bangku Astrand-Rhyming. $\mathrm{VO}_{2}$ maks merupakan suatu ukuran seberapa bugar (fit) seseorang, dengan menyatakan volume oksigen yang dikonsumsi tubuh per menit sehingga satuannya adalah $\mathrm{ml} / \mathrm{kg} /$ menit (Marley 1982; Sharkey 1991; Quinn 2008). Pada Tabel 4 dapat dilihat bahwa kebugaran fisik BF dan MVM mengalami

Tabel 4. Kebugaran Fisik berdasarkan Denyut J antung dan $\mathrm{VO}_{2}$ maks menurut Perlakuan

\begin{tabular}{llcccc}
\hline \multicolumn{2}{c}{ Kebugaran Fisik } & BF $(\mathbf{n = 1 1 )}$ & MVM (n=11) & P (n=12) & $\mathbf{p}^{1}$ \\
\hline \multirow{2}{*}{ Denyut jantung } & Sebelum & $37.2 \pm 4.4$ & $35.9 \pm 4.6$ & $36.6 \pm 5.9$ & 0.842 \\
(kali/ 15 detik) & Sesudah & $33.7 \pm 4.4$ & $33.3 \pm 5.1$ & $36.9 \pm 4.2$ & 0.130 \\
& $\Delta$ Denyut & $-3.5 \pm 7.1$ & $-2.6 \pm 4.9$ & $0.3 \pm 5.5$ & 0.282 \\
\hline \multirow{2}{*}{$\mathrm{VO}_{2}$ maks } & Sebelum & $39.5 \pm 4.6$ & $41.1 \pm 6.0$ & $40.9 \pm 7.5$ & 0.787 \\
$(\mathrm{~mL} / \mathrm{kg} /$ menit) & Sesudah & $44.3 \pm 7.2$ & $45.5 \pm 9.4$ & $39.8 \pm 5.9$ & 0.175 \\
& $\Delta \mathrm{VO}_{2}$ maks & $4.8 \pm 9.8$ & $4.4 \pm 8.4$ & $-1.2 \pm 6.2$ & 0.160 \\
\hline
\end{tabular}


kenaikan sedangkan pada $\mathrm{P}$ menurun. Pada BF dan MVM denyut jantung pasca uj i bangku turun sehingga $\mathrm{VO}_{2}$ maks naik, ini menandakan kerja jantung paru bertambah efisien. Meskipun demikian, perbedaan $\Delta$ kebugaran fisik antar perlakuan setelah suplementasi hanya nyata pada nilai $p>0.005$. Hal ini menunjukkan bahwa peningkatan $\mathrm{Hb}$ dan SF yang terjadi di atas belum dapat menaikan kebugaran fisik pekerja wanita secara nyata.

Secara umum kebugaran fisik semua pekerja wanita sudah tergolong baik hingga superior, mungkin karena mereka terbiasa bekerja keras. Rutinitas aktivitas fisik yang dilakukan oleh pekerja wanita termasuk sedang hingga berat. Para pekerja wanita terbiasa bekerja dalam rentang waktu yang cukup panjang (810 jam) dan istirahat pada rentang waktu yang cukup singkat (1 jam). Dengan demikian jantung dan paru-paru mereka sudah terlatih bekerja pada kondisi bekerja sedang hingga berat dan dapat memanfaatkan waktu istirahat dengan baik. Hal ini sesuai dengan Sharkey (1991) dan Lee et al. (2008), yang menyatakan bahwa denyut jantung istirahat pada orang yang yang terlatih lebih rendah (lebih cepat turun setelah melakukan aktivitas berat) dibandingkan dengan yang tidak terlatih. Seseorang yang memiliki kapasitas aerobik tinggi memiliki denyut jantung pasca kerja (pemulihan) yang lebih rendah, karena denyut jantung mereka tidak naik terlalu tinggi pada saat melakukan pekerjaan fisik.

Pada analisis lanjut yang dilakukan khusus pada pekerja wanita anemia $(\mathrm{Hb}<120 \mathrm{~g} / \mathrm{L}$, $n=28)$, maka rerata penurunan laju denyut jantung yang terjadi pada BF $(n=9), \operatorname{MVM}(n=9)$ dan $P(n=10)$ berubah menjadi $-2.2,-1.5$, dan 1.6 kali ( $p>0.098)$, sedangkan peningkatan $\mathrm{VO}_{2}$ maks menjadi 3.32, 3.47, dan $-2.42 \mathrm{~mL} /$ $\mathrm{kg} /$ menit $(p>0.087)$. Ini berarti ada kecenderungan kebugaran fisik pada BF dan MVM naik sebesar 9 persen dan 10 persen, sedangkan pada $P$ turun sebesar -4 persen. Selain itu, perbedaan $\Delta$ laju denyut jantung dan $\mathrm{VO}_{2}$ maks antara BF dan MVM dengan $P$ meningkat $(p>0.005)$. Kebugaran fisik pekerja wanita yang anemia pada BF dan MVM jika dikoreksi dengan $P$ adalah cenderung naik sebesar $5.7 \mathrm{~mL} / \mathrm{kg} /$ $\min (13 \%)$ dan $5.9 \mathrm{~mL} / \mathrm{kg} / \mathrm{min}(14 \%)$. Kebugaran fisik pekerja wanita anemia cenderung turun bila tidak mengonsumsi suplemen.

\section{KESIMPULAN}

Status gizi pekerja wanita yang semula memiliki kadar $\mathrm{Hb}$ marginal sesudah suple- mentasi cenderung lebih baik yaitu semula yang termasuk kurus 12 persen dan normal 70 persen menjadi 6 persen dan 73 persen. Sebagian besar pekerja wanita mengalami defisit vitamin $\mathrm{C}$, kalsium dan Fe; namun demikian semua memiliki kebugaran fisik yang baik hingga superior.

Efek bersih suplementasi tiga kali per minggu dengan BF dapat meningkatkan kadar $\mathrm{Hb} 8.6 \mathrm{~g} / \mathrm{L}$ (8\%) dan SF $10.1 \mathrm{ug} / \mathrm{L}$ (42\%), sedangkan dengan MVM dapat meningkatkan Hb $6.8 \mathrm{~g} / \mathrm{L}(6 \%)$ dan SF $2.9 \mathrm{ug} / \mathrm{L}$ (10\%) pada pekerja wanita yang semula memiliki kadar $\mathrm{Hb}$ marginal. Suplemen BF dan MVM dapat meningkatkan kebugaran fisik pekerja wanita yang anemia sebesar 13 persen dan 14 persen. Kapsul BF lebih baik dalam meningkatkan status besi, sedangkan MVM cenderung lebih baik dalam meningkatkan kebugaran fisik pekerja wanita yang anemia.

\section{UCAPAN TERIMA KASIH}

Penulis mengucapkan terima kasih kepada Neys-Van Hoogstraten Fondation yang telah mendanai penelitian pendahuluan; kepada Kementerian Pendidikan Nasional yang telah membantu mendanai penelitian ini melalui $\mathrm{Hi}$ bah Kompetitif Penelitian Sesuai Prioritas Nasional tahun 2010; dan kepada kantor WHO di Indonesia yang telah menyumbangkan suplemen MVM.

\section{DAFTAR PUSTAKA}

Ahmed $F$ et al. 2005. Efficacy of twice-weekly multiple micronutrient supplementation for improving the hemoglobin and micronutrient status of anemic adolescent schoolgirls in Bangladesh. Am J Clin Nutr, 82, 829-35.

[BPPK Depkes RI] Badan Penelitian dan Pengembangan Kesehatan Departemen Kesehatan RI. 2008. Laporan Hasil Riskesdas 2007. Depkes RI, J akarta.

Briawan D. 2008. Efikasi suplementasi besimultivitamin terhadap perbaikan status besi remaja wanita. Disertasi. SPS, IPB, Bogor.

Carley A. 2003. Anemia: When is it iron deficiency?. Pediatric Nursing, MarchApril, 29 (2), 127-133. 
Ekayanti I. 2005. Efek pemberian gizi mikro terhadap keberhasilan suplementasi zat besi pada wanita anemia. Disertasi. PPS Universitas Airlangga, Surabaya.

Gibson RS. 2005. Principles of Nutritional Assessment. Second Edition. Oxford University Press, New York.

[INACG] International Nutritional Anemia Consultative Group. 2003. Integrating programs to move iron deficiency and anemia control forward. Report of the 2003 International Nutritional Anemia Consultative Group Symposium: Marrakech, Morocco, 6 February 2003.

Indriani Y, Riyadi H, \& Zuraida R. 2011. Study on the Nutritional Status and Physical Fitness of the Non Pregnant Woman Workers to Support Household Socioeconomy. Research Report. Department of Agricultural Socio-Economics, Faculty of Agriculture, University of Lampung with Neys-Van Hoogstraten Foundation, Bandar Lampung.

[IOM-FNB] Institute of Medicine, Food and Nutrition Board. 2001. Dietary Reference Intakes for Vitamin A, Vitamin K, Arsenic, Boron, Chromium, Copper, lodine, Iron, Manganese, Molybdenum, Nickel, Silicon, Vanadium, and Zinc. National Academy Press, Washington.

Lee 0 et al. 2008. Correlation between YMCA step-test and maximum oxygen consumption (V02max) as measurement tools for cardiorespiratory. Korean J Epidemiol, 30 (1), 73-81.
Li R. et al. 1994. Functional consequences of iron supplementation in iron deficient female cotton mill workers in Beijing, China. Am J Clin Nutr, 59, 908-913.

Marley WP \& Linnerud AC. 1976. AstrandRyhming Step Test Norms For College Students. Br J Sports Med, J un 10 (2), 76-9.

. 1982. Health and Physical Fitness. Saunders College Publishing, Philadelphia.

Murray-Kolb LE \& Beard J L. 2007. Iron treatment normalizes cognitive functioning in young women. Am J Clin Nutr, 85, 77887.

Quinn E. 2008. What Is $\mathrm{VO}_{2}$ Max? http:// www.about.com/localhost $\quad\left[13^{\overline{\text { Feb }}}\right.$ 2009].

[RHSFNS] Rob's Home of Sport, Fitness, Nutrition, and Science. 2008. Fitness Testing Queens College Step Test. www.topendsports. com [1 J an 2009].

Sharkey BJ. 1991. New Dimension in Aerobic Fitness. Human Kinetics Books, Illinois.

UNICEF/WHO/UNU. 1999. Composition of a multi-micronutrient supplement to be used in pilot programmes among pregnant women in developing countries. Report of a Unicef, WHO, UNU workshop UNICEF/ WHO/ UNU, New York.

[WB] World Bank. 2006. Repositioning Nutrition as Central to Development a Strategy for Large-Scale Action.The World Bank, Washington DC. 